\title{
The US Rebalance and Southeast Asia
}

\author{
A Work in Progress
}

\begin{abstract}
This article assesses Southeast Asian views of the US "rebalance," examining reactions to US military deployments, military assistance to partners, and support for Southeast Asian diplomacy on South China Sea conflicts. Although not ostensibly designed to contain China, the rebalance provides Southeast Asia with hedging options against more assertive PRC actions in the South China Sea.
\end{abstract}

KEYWORDS: US rebalance, ASEAN, multilateral security, South China Sea

\section{INTRODUCTION}

Washington's strategic goals for Asia have been remarkably consistent since the end of the Second World War, regardless of the party in power. Possessing the world's most powerful navy and as the preeminent global maritime trader, the country has tasked its Pacific Command with maintaining the freedom of the sea lines of communication (SLOCs). Free trade is the basis of liberal democratic capitalism-the international system promoted by the United States at Bretton Woods. US armed forces deployments in Asia were designed to prevent the rise of any regional hegemon that could constrain America's political, economic, and security interests in the Pacific. The bilateral US-Asian alliances established in the I950s and I960s provided bases and partners for US forces that buttressed their regional deployments. In the last two decades, as Asian states matured economically, Washington became more interested in multilateral cooperation and most recently in sharing responsibility for maintaining regional order. ${ }^{1}$

Sheldon W. Simon is a Professor in the School of Politics and Global Studies at Arizona State University, Tempe, USA. The author wishes to thank an anonymous reviewer for helpful suggestions. Email: <shells@asu.edu>.

I. For a thorough review of US grand strategy and a projection of its future, see Stephen Brooks, G. John Eikenberry, and William Wohlforth, "Don't Come Home, America: The Case against Retrenchment," International Security 37, no. 3 (Winter 2012-13): 7-51.

Asian Survey, Vol. 55, Number 3, pp. 572-595. ISSN 0004-4687, electronic ISSN 1533-838X. (c) 2015 by the Regents of the University of California. All rights reserved. Please direct all requests for permission to photocopy or reproduce article content through the University of California Press's Rights and Permissions website, http://www.ucpressjournals.com/reprintInfo.asp. DOI: IO.I525/AS.20I5.55.3.572. 
For most of the past seventy years, the United States focused on Northeast Asia, where its two primary allies-Japan and the Republic of Korea-are both located and where wars could break out on the Korean Peninsula and across the Taiwan Strait. With the exception of America's ten-year involvement in the Second Indochina War (1965-1975), Southeast Asia was clearly a secondary security interest. That assessment changed after 9/Ir. Suddenly, in response to radical Islamism, the George W. Bush administration designated Southeast Asia, home of the world's most populous Muslim country, Indonesia, the "second front" of the "global war on terror." Throughout the Bush years (200I-2008), Southeast Asia became a major security policy concern-a concern, however, very narrowly construed through a counterterrorism lens. Thus, Washington provided technical support through the FBI to assist Indonesia's creation of a special counterterrorist police unit, Densus 88, that targeted Jemaah Islamiya, the group responsible for the 2002 Bali bombings and a number of subsequent explosions in Indonesia through 2009. In the Philippines, US Special Forces were invited to train elements of the Philippine army in Mindanao to suppress the radical Islamic criminal gang Abu Sayyaf, also affiliated with al-Qaeda. It seemed that counterterrorism was the sole interest of the United States in Southeast Asia through most of the first decade in the new century. With the advent of the Obama administration, this approach to Southeast Asian security changed.

\section{THE REBALANCE: A NEW STRATEGY?}

Within a year after the Obama administration came into office, the United States decided to revise its Asia strategy. Its predecessor's focus on the Middle East and South Asia, with counterinsurgent wars in Iraq and Afghanistan, were terminated in the former (end of 20II) and is being wound down in the latter (US troops out by the end of 20I4). For Southeast Asia, a new concern was generated by China's growing maritime territorial assertiveness in the South China Sea and the enhanced maritime abilities of the People's Liberation Army Navy (PLAN) to enforce its claims. Initially, the Obama administration objected to Chinese pressure on American oil companies to refrain from assisting Vietnam in developing its offshore oil resources. Subsequently, in May 2009, Beijing challenged a surveillance ship, USNS Impeccable, operating in China's exclusive economic zone (EEZ) off Hainan Island, an action deemed perfectly legal under most interpretations of the UN Convention on 
the Law of the Sea (UNCLOS). In July 20I2, US secretary of state Hillary Clinton declared at the annual ARF that the United States had a "national interest" in freedom of navigation in the South China Sea and would work to protect it. ${ }^{2}$ This statement was soon followed by what appeared to be a new conception of the American strategic role in Asia, first referred to as a pivot and subsequently as a rebalance.

Throughout 20I3, a number of high-level US officials have addressed this rebalance, among them National Security Adviser Tom Donilon, Undersecretary of Defense Ashton Carter, Assistant Secretary of Defense for Asian and Pacific Security Affairs Mark Lippert, and Admiral Samuel Locklear III, commander of the US Pacific Command. ${ }^{3}$ Although the Obama administration's Asia rebalance emphasizes Southeast Asia and a "whole of government" approach, incorporating diplomacy, educational support, and international trade, the primary concerns of Southeast Asian leaders are fixed on security relations. As Donilon stated in a major foreign policy address to the Asia Society on March II, 20I3: "The United States is implementing a comprehensive multidimensional strategy: strengthening alliances; deepening partnerships with emerging powers; building a constructive relationship with China; empowering regional institutions; and helping to build a regional economic architecture that can sustain shared prosperity." In the same speech, he averred that the US rebalance "is also a response to the strong demand signal from leaders and publics across the region for US leadership, economic engagement, and sustained attention to regional institutions and defense of international rules and norms." Donilon also reiterated a point made a few months earlier, that within Asia the rebalance is designed "to recognize the growing importance of Southeast Asia."

The Obama administration accentuates the buildup of traditional air and naval assets in the region, collaboration with partners and allies to develop their own defense capabilities, and cooperation with Asian states in regional political institutions, including the many iterations of the Association of Southeast Asian Nations (ASEAN). Giving pride of place to the East Asia Summit (EAS)—which the United States joined in 20II-Donilon noted

2. A good review of these developments is found in Carlyle A. Thayer, South China Sea: The Drivers behind Current Tensions, Thayer Consultancy Background Brief, May I8, 20I3, 2-3.

3. Much of the following analysis is drawn from Sheldon Simon, "US-Southeast Asian Relations: Military Commitments and Human Rights Concerns," Comparative Connections I5, no. I (May 2013), 55-56, <http://csis.org/program/comparative-connections>. 
that the president would attend the summit every year and that the US goal is "to elevate the EAS to the premier forum for dealing with political and security issues in Asia." Among the ASEAN states, the national security adviser singled out US allies Thailand and the Philippines, as well as Indonesia. The relationship with Jakarta is now termed a Comprehensive Partnership, recognizing the country's important role as a leader in ASEAN-based political-security matters.

In a speech to the United States-Indonesia Society in Jakarta on February 8, 2013, Admiral Locklear outlined the reasons behind the US rebalance:

The many nations who associate themselves here include five of our nation's seven treaty allies, the largest economies of the world.... The most populous nations of the world are also represented, which also include the first, second, and third largest democracies.... Nine of the world's largest ports are in the Asia-Pacific. The sea lanes here are the busiest in the world through which pass over half the entire world's container cargo every day and over 70 percent of ship-based energy.... The Asia-Pacific is also the most militarized area in the world with seven of the world's ten largest standing militaries, the world's largest and most sophisticated navies, and five of the world's declared nuclear states. ${ }^{4}$

Assistant Secretary of Defense Mark Lippert presented an overview of the rebalance components on February 27, 2013, to a Center for Strategic and International Studies-Georgetown University US Studies Center conference titled The Rebalance: One Year Later. ${ }^{5}$ Lippert stressed the "whole of government approach" to the rebalance, actually downplaying the role of the Department of Defense as "supporting the diplomatic, economic, development, and cultural pieces." Equally important was "a strong bilateral relationship with China," including the US's inviting the PRC to participate in the biannual Rim of the Pacific exercise. The bulk of the assistant secretary's address was devoted to revitalizing partnerships throughout the region. Its Southeast Asian features included:

4. "Resilience and the Asia-Pacific Rebalance," Admiral Samuel L. Locklear III, Commander of the US Pacific Command, at the United States-Indonesia Society, Jakarta, February 8, 2013.

5. Lippert's address may be found in the Nelson Report, February 28, 2013. 
- The US-Thailand Joint Vision statement is updated for the first time in fifty years, now emphasizing interoperability for Southeast Asian security.

- The Washington Declaration with New Zealand provides Wellington with ship visits to US ports and military staff talks not seen for the past twenty-five years.

- In cooperation with Thailand, Burma (Myanmar) is invited to observe the 2013 Cobra Gold exercise. US talks with Naypyidaw focus on its armed forces' commitment to human rights.

- In Malaysia, a US aircraft carrier for the first time visits the South China Sea port of Kota Kinabalu.

- Enhanced engagement with Indonesia's military and a new memorandum of understanding with Vietnam on defense.

- In Australia, 2012 witnessed the first company-size rotation of 250 US marines for joint training near Darwin-a number scheduled to reach 2,500 in due course.

- The United States is helping build Philippine maritime capabilities with ships, coastal radars, and more frequent deployments of US Seventh Fleet assets.

- In Singapore, the first of four littoral combat ships has been deployed for bi- and multilateral exercises.

While all of the above are essentially bilateral components of the rebalance, a renewed emphasis on ASEAN and its offspring is also apparent. As assistant secretary Lippert put it, there are "unprecedented amounts of senior level engagement with ASEAN and the ADMM+ [ASEAN Defense Ministers Meeting plus defense dialog partners]." He went on to note that the Department of Defense would send a full-time official to the US Mission to ASEAN and would continue to be deeply engaged in the ADMM+ Experts Working Group on Counter-Terrorism, co-chaired with Indonesia.

\section{An Enhanced US Military Posture in Southeast Asia and Alliance Strength}

While the architects of the rebalance insist that it is a whole-of-government enterprise, with civilian agencies and activities being as important as the armed forces and economic initiatives such as the Trans-Pacific Partnership, and a sign of America's commitment to prosperity as much as security, 
nonetheless US military capabilities are seen in the Asia-Pacific as the centerpiece of Washington's initiative. A brief look at the Pacific Command's order of battle in 2012 illustrates its formidability: six aircraft-carrier battle groups, I80 ships, and I,500 aircraft, backed by Ioo,ooo troops. ${ }^{6}$ By 2020, $60 \%$ of the US Navy will be deployed in the Pacific. New platforms will dominate, including Virginia-class submarines, fifth-generation combat aircraft such as the F-22 and F-35, P-8 aircraft, the latest cruise missiles, a new strategic bomber, and a range of information, surveillance, and reconnaissance assets such as the Global Hawk and MQ-9 Reaper unmanned aerial vehicles, as well as venerable U-2 aircraft. Among other advantages, these systems will permit US forces to operate beyond the effective range of China's anti-access/area denial capabilities, thus diminishing the PLA's deterrent strength.

Of course, ever since the end of the Korean War (in 1953), the United States has had a significant presence in East Asia. The Pacific Command has been the largest of the combatant commands, with the most extensive geographic responsibilities, from the mid-Pacific to the western Indian Ocean. Nevertheless, in the last decade, elements of the Pacific Command's ships, aircraft, and ground forces have been redeployed to support US actions in Iraq and Afghanistan. Despite the modernization of the armed forces mentioned in the preceding paragraph, the combination of the pre-sequester defense budget cut of $\$ 500$ billion out to 2020 and the sequester's removal of a similar amount over the same time period is also impacting the Pacific Command. Unsurprisingly, however, given the rebalance to Asia, the US Navy is the only service scheduled to grow in this time period, adding 8,ooo sailors over the next six years, building eight new ships, and buying I65 aircraft. The Marine Corps also plans to add personnel while scaling back equipment and facilities upgrades. Ever innovative, the Marines are now using cargo ships to make up for the shortage of amphibious warfare vessels. US forces in Asia are conducting more exercises than before, and

6. The figures are cited in Douglas Stuart, "San Francisco 2.0: Military Aspect of the U.S. Pivot to Asia," Asian Affairs 39, no. 4 (October-December 20I2), 2II. Also see Carlyle A. Thayer, "China's Naval Modernization and U.S. Rebalancing: Implications for Stability in the South China Sea,"

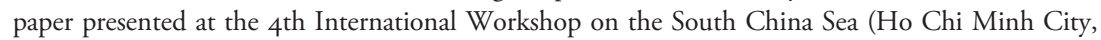
November I8-2I, 2012), I5-I6; Deputy Secretary of Defense Ashton Carter, "The Rise of Asia and New Geopolitics in the Asia-Pacific Region," prepared for delivery at the Indonesian Defense University, Jakarta, March 20, 20I3. 
such showcase events as the annual Cobra Gold in Thailand are bigger than ever. $^{7}$

Although the United States has expanded and modernized its partnerships with several Southeast Asian states, created regular security dialogues involving senior officials from each state, assisted partners in developing their own defense capabilities, modernized local basing facilities, and engaged in multilateral exercises in addition to the ubiquitous bilateral activities, there has been little movement toward a more networked structure among partners and allies. ${ }^{8}$ This means that while virtually all Southeast Asian armed forces exercise and train with their US counterparts, their military relations with each other are almost entirely bilateral-the exception being the Malacca Straits patrols involving Indonesia, Malaysia, Singapore and-in its air force component-Thailand. ${ }^{9}$ As Carl Baker and Brad Glosserman point out, the US emphasis on Asian bilateral alliances as the center of its strategic approach to the Pacific is understandable: "Alliances represent sunk costs. The US has invested considerable resources in sustaining each of the bilateral alliances, and it made sense to leverage these relationships." ${ }^{10}$ Over time, these arrangements create familiarity among bureaucrats and policymakers and lead to a degree of understanding of each other's interests and values. Moreover, the latest joint vision statements can lead to an expansion of security interests, including cybersecurity, surveillance, and reconnaissance, as well as humanitarian assistance and disaster response-the latter becoming a significant activity of America's Asian alliances since the late 2004 Southeast Asian tsunami.

Nevertheless, US fiscal realities growing out of the recent US economic crisis and the sequestration mean that alliance partners will have to contribute more to maintain the system. Unfortunately, most Southeast Asian states do

7. Jennifer Steinbrunner, "Back in Asia, Hagel Pursues Shift to Counter China's Goals in the Pacific," New York Times, October 3, 20I3; Carlyle Thayer, Background Brief (Thayer Consultancy), September 30, 20I3; Paul McLeary, "US Pacific Shift Carries Heavy Logistics Price Tag," Defense News, July 15, 20I3, II; Sean Fellman, Gina Harkras, and Dan Lamothe, "U.S. Defense Budget Proposal Calls for More Sailors, Shifts to Asia-Pacific," Defense News, April I5, 2013, I2.

8. Carl Baker and Brad Glosserman, "US Alliances in the Asia-Pacific: Doing More and Expecting Less," in The Future of US Alliances in the Pacific, ed. Baker and Glosserman (Honolulu: Pacific Forum, 20I3), 80.

9. Sheldon W. Simon, "Safety and Security in the Malacca Straits: The Limits of Collaboration," Asian Security 7, no. I (Spring 20II), 27-43.

Io. Baker and Glosserman, "US Alliances in the Asia Pacific," 87. 
not have the fiscal capacity to do so. Therefore, while the US Department of Defense 2012 Strategic Guidance calls for enhanced alliance cooperation, it does so by insisting that these arrangements be "innovative, low cost, and small footprint approaches to achieve our security objectives" (emphasis in the original)..$^{11}$

By 20I3, the United States had identified six strategic partners. Singapore probably tops the list, though it has no formal defense treaty with the United States. Nevertheless, it is the state where Washington has deployed its latest Pacific Fleet vessel, the littoral combat ship. Next came the Philippines and Thailand, with which Washington has formal defense commitments; then Indonesia, Malaysia, and Vietnam, with which Washington is developing strategic partnerships - an expression of security importance for both sides somewhat short of a formal commitment. Although host of the world's largest annual military exercise, Cobra Gold, Thailand has evolved from a staunch Cold War ally (particularly vis-à-vis then-aggressive Vietnam) to a somewhat restrained security partner whose strategic policy is more one of hedging between Washington and Beijing. ${ }^{12}$ Not having a territorial claim in the South China Sea, Bangkok does not view the PRC as a threat but rather as an alternative arms supplier that is less expensive and does not impose political conditions on sales as does the United States. Thus, interoperability between the US and Thai forces has been declining, at a time when the Obama administration is building security ties with Singapore, Indonesia, and Vietnam. Unlike the Philippines, Thailand has not permitted American involvement in its internal security situation, especially in the decades-long conflict in the south. Nevertheless, in addition to Cobra Gold, US and Thai armed forces hold over 40 combined military exercises per year, and tens of thousands of Thai military officers have taken part in US armed forces training and educational programs. ${ }^{13}$

II. Peter N. Shinn, Peter A. Garretson, and Adam Lothar, "Time for Airpower Diplomacy in the Asia-Pacific," The Diplomat, May 28, 2013, <http://thediplomat.com/2013/05/28;time-for-airpowerdiplomacy-in-the-pacific $>$.

I2. A good discussion of the relationship is found in Catharin Dalpino, An Old Alliance for a New Century: Reinvigorating the U.S.-Thailand Alliance, Special Report no. 40, National Bureau of Asian Research, June 20I2. For a current complaint that Thailand is no longer sending its own best forces to participate in Cobra Gold, see Simon, "Military Commitments and Human Rights Concerns," 57.

I3. David Capie, "Structures, Shocks and Norm Change: Explaining the Late Rise of Asia's Defense Diplomacy," Contemporary Southeast Asia, 35, no. I (April 2013): 6. 


\section{Security Multilateralism}

The Obama administration has declared that ASEAN-centered politicalsecurity institutions such as the ARF, the ADMM+, and the EAS are key components of the rebalance. This is particularly true and relatively uncontroversial for those security concerns labeled nontraditional, for which cooperation benefits all since nontraditional security activities are not based on adversarial postures. These include transnational crime, piracy, humanitarian assistance and disaster relief, nonproliferation of weapons of mass destruction, and environmental pollution. Nontraditional challenges have led to voluntary ad hoc coalitions created to solve particular problems rather than the established Cold War alliances. ${ }^{14}$ Southeast Asian examples of such coalitions for humanitarian disasters include the 2004 Boxing Day tsunami, the response to which was led by the United States, and the December 2008 Cyclone Nargis in Myanmar, for which ASEAN provided leadership. The considerable American component in responding to both of these natural disasters bolstered the US argument that its Asian alliances remained crucial for meeting transnational challenges.

While ASEAN-centered organizations take the lead in Southeast Asian security diplomacy in both Track I and Track II bodies, particularly through the ADMM and ARF, as See Seng Tan and Bhubindar Singh have recently pointed out, "Southeast Asia's defense regionalism is largely defined by informal confidence building with a highly limited adoption of preventive diplomacy efforts. This is due to a lack of strategic imperative and institutional coherence in regional defense cooperation." ${ }^{15}$ In short, Southeast Asian security discussions are still dominated by each individual state's policy concerns, for which there are few standing arrangements for or commitment to regional responses to threats and challenges. The most that can be said for ASEAN's nascent Political-Security Community is that it created the ADMM, which has provided an opportunity for its ten members' senior defense officers to meet regularly and discuss their common concerns. ASEAN defense officials have also agreed, along with their external partners, to establish a network of ASEAN peacekeeping centers,

I4. Victor Cha, "Complex Patchworks: US Alliances as Part of Asia's Regional Architecture," Asia Policy II (January 20II): $38-39$.

I5. Seng Tan and Bhubindar Singh, "Introduction: Defense Diplomacy in Southeast Asia," Asian Security 8, no. 3 (September-December 2012): 227. 
though the actual responsibilities of these new organizations remain a topic for future discussions. ${ }^{16}$

The United States applauds and supports all of these activities because they link to the Obama administration's policy of building the capabilities of countries with which Washington has partnered or allied, thus adding to interoperability with US forces. By building credible approaches to its forward presence through diplomacy, trade and investment, alliance commitments, civilian humanitarian responses, and maritime capacities, the United States demonstrates the continued importance of alliances and partnerships to Southeast Asia host countries. ${ }^{17}$ An ongoing example of Washington's appeal to ASEAN states on behalf of a regional security effort is the tenyear-old Proliferation Security Initiative (PSI). Designed to prevent the proliferation of weapons of mass destruction (WMD), primarily by North Korea, the PSI now has I5 members from Australia, Europe, and Asia, as well as North America. The PSI is a political arrangement-not a treatywhose members agree to interdict WMD shipments over land, in the air, and at sea to and from states and nonstate actors who may be proliferators. Activities include intelligence sharing and coordination among PSI military and law enforcement. While some states object that it may be violating UNCLOS, over time the PSI has gained traction and is credited with a number of successful interdictions. As for the rebalance, the United States works with PSI members to build their interdiction capacities. The Philippines and Brunei credit their membership with enhancing their maritime security capabilities. ${ }^{18}$

\section{Intractable Diplomacy: The South China Sea Code of Conduct}

While the United States is not a claimant to any South China Sea features and supports no country's territorial demands, the Obama administration has backed ASEAN's insistence that the conflicts be resolved peacefully through the UNCLOS provisions, as well as the 1967 ASEAN Treaty of Amity and

I6. Seng Tan, “Talking Their Walk'? The Evolution of Defense Regionalism in Southeast Asia," Asian Security 8, no. 3 (September-December 20I2), 238.

17. Michael Mazarr and the NDI Strategy Study Group, "Discriminate Power: A Strategy for a Sustainable National Security Posture," Philadelphia Papers I2 (May 2013), I5.

I8. David Santoro and Shahriman Lockman, "The Proliferation Security Initiative in ASEAN: A Glass Half Full or Half Empty?” PacNet Newsletter 8, January 28, 2013. 
Cooperation in Southeast Asia (TAC), to which China and the United States have adhered. ${ }^{19}$ Both UNCLOS and the TAC require that all disputes be settled peacefully and all parties abjure the threat or use of force. China is essentially ignoring those provisions in provocatively deploying more warships and patrol boats around those South China Sea features it claims and in obstructing fishing craft from other countries_-especially the Philippines and Vietnam-from reaching their traditional fishing locations.

Over the past few years, the United States has relocated forces and military equipment to Southeast Asia and raised the South China Sea disputes regularly in regional meetings such as ASEAN summits, the ARF, the ADMM+, and the EAS. The PRC denounces these American actions as "meddling" and an effort to internationalize the problem. Beijing argues that the South China Sea is none of America's business and that the contested claims should be resolved bilaterally between China and each of the other claimants. Other than a Declaration of Conduct signed in 2002-nonbinding, and with no enforcement provisions - there is no conflict-management mechanism for the South China Sea. The Obama administration has endorsed ASEAN efforts to create a formal binding Code of Conduct between ASEAN and China that would establish "rules of the road" and prevent belligerent actions. By mid-20I2, the ASEAN states had agreed on the components of such a code, though China continues to throw obstacles in the path of further negotiations, insisting that talks can only begin when "the time is ripe." According to Ian Storey, a prominent South China Sea analyst, China asserts that the Philippines and Vietnam — with US backing — violate the Declaration of Conduct's prohibition of unilateral and provocative actions, allegations reciprocated by Manila and Hanoi against the PRC. China is suspicious of any Code of Conduct drafted by ASEAN without Beijing's participation. Moreover, Beijing sees the US rebalance as a policy designed to contain China's South China Sea aspirations but not those of the other claimants. ${ }^{20}$ ASEAN as an institution has to balance the interests of its members (those

I9. For a thorough assessment of the various states' positions on the South China Sea conflicts, see Sheldon W. Simon, "Conflict and Diplomacy in the South China Sea: The View from Washington," Asian Survey 52, no. 6 (November-December 2012): 995-IOI8.

20. Ian Storey, "Slipping Away? A South China Sea Code of Conduct Eludes Diplomatic Efforts," East and South China Seas Bulletin (Center for a New American Security) II (March 2O, 20I3): 4-6; Carlyle Thayer, "Securing Maritime Security in the South China Sea: Norms, Legal Regimes and 'Realpolitik'," paper presented at the annual meeting of the International Studies Association, San Francisco, April 6, 2013. 
with South China Sea claims) against those who view positive relations with China as a priority (Laos, Cambodia, Myanmar). Thus, ASEAN rejected a Philippine overture for a united stand against China's aggressive territorial claims at the association's April 2013 meeting in Brunei, insisting that "overlapping claims are for claimant states to deal with" — a statement more akin to the PRC's position than that of ASEAN's claimant members. ${ }^{21}$ However, it must be remembered that all ASEAN decisions are made by consensus, so even a single disagreement means that no ASEAN position is taken.

\section{The Rebalance and the Philippines and Vietnam}

While the United States is involved in assisting all Southeast Asian allies and partners in developing their military capacities, the focus of the rebalance is on the Philippines and to a smaller extent Vietnam. Relations with Hanoi are more diplomatic than operational. In contrast, America's relations with the Philippines could constitute a litmus test for the effectiveness of US military assistance and diplomatic support. In 2012, Manila inaugurated a five-year, $\$ 900$ million modernization program that emphasizes the acquisition of combat jets, anti-ship missiles, patrol boats, and naval helicopters. Washington's support for this program was announced through the tripling of military aid and an increased US presence, with more visits by warships, nuclear submarines, and military personnel. ${ }^{22}$ So far, the Obama administration has provided two refurbished retired US Coast Guard cutters, with the prospect of a third. Meanwhile, the Philippines has presented Washington with a lengthy wish list, including coastal radar, long-range patrol aircraft, sealift vessels, offshore patrol boats, naval helicopters, air defense radar, jet trainers, surface attack craft, anti-ship missiles, and a submarine. Whether the Philippines could actually maintain this array of equipment if it became available is problematic. Then Deputy Secretary of Defense Ashton Carter promised only help in building Philippine maritime security and domain awareness, which would probably be translated into coastal radars, patrol craft, and intelligence sharing. ${ }^{23}$

2I. "ASEAN Rejects Aquino Push for Stand against China over SCS," Daily Tribune Online (Manila), April 26, 20I3.

22. Richard Javad Heydrian, "Philippines Takes New Aim at China," Asia Times Online, February 2I, 2OI3, <http:/wwwatimes.com/atimes/SoutheastAsia/SEA-OI-2IO2I3.html>.

23. Thayer, "Securing Maritime Security," 22. 
China's control of several features within the Philippines' EEZ, and the PRC's de facto acquisition of Scarborough Shoal in 20I2, have led the Aquino administration to adopt a hedging strategy. Manila has raised the prospect of invoking the I95I Philippine-US Mutual Defense Treaty if armed clashes develop with Chinese ships in disputed areas of the Spratly Islands. At the same time, the Philippines signed a Greater Defense Cooperation Agreement with Japan in July 2012 to acquire I2 new patrol boats for the Philippine Coast Guard. Foreign Minister Alberto Del Rosario stressed that "the US is the sole strategic partner of the Philippines" and that Manila welcomes an enhanced American military presence. ${ }^{24}$ The prospect of invoking the Mutual Defense Treaty potentially creates a dilemma for Washington. The Obama administration does not foresee the rebalance as provoking a war with China-quite the opposite. It hopes that an emphasis on diplomacy backed by military deployments will encourage Beijing to accept multilateral negotiations led by ASEAN over the South China Sea. However, the Philippine-US treaty could lead to "entrapment" for Washington, in which it must risk confrontation with China or undermine the credibility of its other Asian defense commitments. This outcome is desired by neither Washington, nor Beijing, nor Manila.

In late May 20I3, Philippine President Benigno Aquino III announced a $\$$ I. 8 billion defense upgrade to defend the country's maritime territory against "bullies." By 20I7, according to this plan, the Philippines will acquire two new frigates, three fast patrol boats, two anti-submarine helicopters, and eight amphibious assault platforms. ${ }^{25}$ While Manila would undoubtedly appreciate US assistance in funding this buildup, Aquino is aware of the financial constraints on the United States resulting from multi-year sequestration, as well as continuing turmoil in the Middle East, which also places demands on the American military aid budget. Nevertheless, the I2-day Balikatan joint exercise with US forces in April 2013 was as elaborate as usual, with 30 US aircraft, including a dozen F-I8s, and three US ships, as well as 8,ooo American and Philippine troops. Further, Secretary Del Rosario urged the United States to rotate more forces through his country and not just wait for joint exercises. ${ }^{26}$ Indicative of this desire to keep American forces close was

24. Cited in Zhao Hong, "China-Philippines Relations Stunted by the South China Sea Dispute," ISEAS Perspective, no. I7 (March 28, 2013), 3-4.

25. "Philippines Boosts Military to Resist 'Bullies'," Agence France Presse World Service, May 2I, 2013.

26. Agence France Presse World Service, April 5, 2013. 
a mid-April 2013 statement by the Philippine foreign secretary that the Philippines was prepared to provide bases for US forces in the event that war broke out in Korea. ${ }^{27}$ (Del Rosario's offer coincided with North Korea's belligerent rhetoric, threatening war against the South and the United States.)

Noteworthy, too, is Japan's new security contribution to the Philippines. In early March 20I3, Tokyo announced the donation of Io new patrol boats for the Philippine Coast Guard, at a cost of \$IIo million. Invigorated JapanPhilippines defense ties serve multiple purposes: (I) providing a link between the Northeast and Southeast Asian components of the rebalance, (2) accelerating Southeast Asia's acceptance of an expanding Japanese defense perimeter, and (3) from Tokyo's perspective, forcing Chinese maritime agencies to further divide their attention between the East and South China Seas. During talks between the Philippine and Japanese foreign ministers in January, Del Rosario stated that his government would back a rearmed Japan if the latter's constitution was amended. A stronger Japan would challenge the threatening presence of China in the region. Moreover, the Philippine Coast Guard could help Japan by monitoring Chinese maritime activities in the South China Sea. Security ties with Japan were further accentuated during President Aquino's Tokyo visit in November 20I4. The Philippine president stated that he viewed Japan as the Philippines' closest ally after the United States and hoped that "somewhere down the line we will have exercises with Japan.” The new Pacific Commander, Admiral Robert Thomas, told Reuters that the United States would welcome a Japanese extension of its air patrols into the South China Sea. While Prime Minister Abe is proposing legislation that would open the way for Japan's military to operate more freely overseas, there has been no public discussion about South China Sea naval air patrols. ${ }^{28}$

27. "Philippines Offers US Military Bases if North, South Korea War Heightens," GMA News Online, April I3, 2013, <http://toolkit.dialog.com/intranet/cgi/present>; for a thorough discussion of the Philippines-US security relationship, see Renato Cruz De Castro, "Territorial Disputes, Realpolitik, and Alliance Transformation: The Case of Twenty-First Century Philippine-US Security Relations," Issues and Studies (Taipei) 49, no. I (March 2013): I4I-78.

28. Julius Cesar I. Trajono, "Japan-Philippine Relations: New Dynamics in Strategic Partnership," Eurasia Review, March I3, 2013, <http://www.eurasiareview.com/05032013-japan-philippinerelations>; Wendell Minnick, "Analysts: Japan Aiding Philippines to Counter China," Defense News, January I4, 20I3, 22. Also see the discussion in Sheldon Simon, "US-Southeast Asian Relations: Diplomatic Gambits," Comparative Connections I6, no. 3 (January 2015), 49; Tim Kelly and Nobuhiro Kubo, "U.S. Would Welcome Japan Air Patrols in South China Sea," Reuters, January 29, 2015. 
While upgrading its navy, air force, and coast guard will be a protracted process, extending over several years and still not sufficient by itself for the Philippines to protect its EEZ and Spratlys claims against a burgeoning PRC navy and civilian maritime agencies, Manila hit upon a different strategy in 2013 - a legal challenge based on UNCLOS. ${ }^{29}$ Under UNCLOS Article 287, the Philippines invoked an arbitral tribunal provision — asking for arbitration, not over sovereignty claims or maritime boundary delimitation, which China has specifically excluded from arbitral jurisdiction, but over the correct interpretation of states' obligations under the treaty, and therefore, appropriate for an arbitral tribunal. Specifically, the Philippines has asked the tribunal to determine whether both Manila's and Beijing's territorial sea, contiguous zone, EEZ, and continental-shelf claims fit UNCLOS guidelines. The purpose of this request is to have China's interpretation declared in violation of the treaty, requiring the PRC to bring its domestic legislation in line with the UNCLOS. Additionally, the Philippines requested that the tribunal determine the legal status of features claimed by the two countries (islands, rocks, low-tide elevations, and submerged banks) and whether those features were capable of generating a maritime zone wider than 12 nautical miles. Manila's goal was to obtain a tribunal ruling that China's claimed submerged features do not quality as islands under UNCLOS and therefore belong to either the Philippines continental shelf or the international seabed. Vietnam, Malaysia, Brunei, and possibly Indonesia hold similar grievances against China, though they have not joined the Philippine legal challenge.

China's claim to the bulk of the South China Sea seems to be based on a map with a nine-dashed-line perimeter encompassing most of the sea. This map, which originated in the I940s, is derived primarily from historical claims that are considered legally weak under UNCLOS. Many of the features within the nine-dash perimeter are as close as 50 nautical miles to the Philippines and as far as 550 nautical miles from China's Hainan Island. Moreover, many are submerged at high tide. If the Philippines can convince

29. This section is based on Carlyle A. Thayer, "China at Odds with U.N. Treaty," United States Naval Institute News, March II, 20I3, <http://news/usni.org/20I3/II/china-at-odds-with-untreaty\#more-225I>; Thayer, "The Philippines Claim to the UNCLOS Arbital Tribunal: Implications for Vietnam," paper presented to the International Workshop on The Sovereignty over Paracel and Spratly Islands, Pham Van Dong University, Quang Ngai City, Vietnam, April 27-28, 20I3; Peter Dutton, The Sino-Philippine Maritime Row: International Arbitration and the South China Sea, Center for a New American Security, March I5, 20I3; Ian Storey, "South China Sea Row Risks Wider Clashes," Asia Times Online, June Io, 20I3, <http://www.atimes.com/atimes/China/CHINoi-Ioo6I3.html>. 
the arbitral panel that China's nine-dash line is invalid, Beijing will have no other legitimate basis for claiming continental-shelf rights in the region. Thus, such features as the oil-rich seabed around Reed Bank would legally be part of the Philippines continental shelf, and Manila could pursue the development of hydrocarbon seabed reserves without Chinese interference. On the other hand, the arbitral tribunal could decide that it has no jurisdiction on these issues, and even if it does agree to hear the case, the process could take up to four years before a decision is rendered.

The preceding analysis constitutes a best-case outcome for the Philippines. In fact, China has already rejected international arbitration. And should the arbitral tribunal reach a decision supporting Philippine claims, there are no enforcement provisions. On the other hand, refusing to participate and ignoring an adverse verdict would have consequences for China. It could convince the PRC's neighbors that China does not abide by the international rules to which it agreed when it ratified UNCLOS. Moreover, if China tries to coerce the Philippines into dropping its case, Beijing will have lent credibility to the "China threat theory." So far, China seems to be following a middle path, putting diplomatic pressure on ASEAN states to convince the Philippines to drop its case. Instead, Beijing claims, it is now ready to negotiate the Code of Conduct.

The United States has backed the Philippine UN initiative. In March 20I3, Deputy Secretary of Defense Ashton Carter told Philippine Foreign Secretary Del Rosario that "the US stands solidly behind the efforts of the Philippines to resolve the maritime dispute in the West Philippine Sea [South China Sea] in a peaceful manner consistent with the rule of law." The Philippine foreign secretary told the press that Secretary Carter had endorsed Manila's arbitral tribunal request. ${ }^{30}$ Washington's diplomatic support for the Philippines' legal claim, combined with enhanced military assistance to build up Philippine armed forces, as well as an increase in US exercises with the Philippine military, encapsulates most of the components of the US rebalance.

\section{Vietnam}

Of the South China Sea claimants, only the Philippines and Vietnam have experienced naval confrontations with China involving significant warlike 
behavior by the latter. As the preceding section of the article shows, the Philippines has pursued several approaches in response, emphasizing its long-standing security ties to the United States. Vietnam's options are more limited. It has improved its air and naval capabilities, primarily with Russian submarines, jet aircraft, and anti-ship cruise missiles. The Russians also have agreed to refurbish Cam Ranh Bay, one of the finest deep-water ports in Southeast Asia. Hanoi may also see Cam Ranh Bay as an attractive location for US ships as part of the rebalancing's "places not bases" strategy — repairs and resupply without the need for formal, politically sensitive basing arrangements.

While the two countries have discussed a strategic partnership, its consummation has foundered on US insistence that it include a separate article on human rights. Unfortunately, the human rights situation in Vietnam continues to deteriorate, though the regime made some gestures in 2013 designed to mollify Washington, including the release of two high-profile dissidents and permission for Amnesty International to visit. ${ }^{31}$ Hanoi would like to move its security relationship with the United States to a new level that would include joint maritime exercises and capacity-building to enhance its anti-access strength. Moreover, Hanoi has asked the United States to share more technical intelligence on China's deployments in the South China Sea. Vietnamese diplomats have told their American counterparts that they would appreciate a greater US voice protesting Chinese violations of UNCLOS. Hanoi will also back more American participation in the region's multilateral organizations. ${ }^{32}$

President Truong Tan Sang's July 2013 visit to Washington, the first highlevel visit in five years, established a new bilateral political-diplomatic mechanism to coordinate security relations. However, no joint plan of action was tabled. So far, US-Vietnam naval contacts remain port-based; as yet, there are no plans for exercises at sea. ${ }^{33}$ Moving the US-Vietnam military relationship to a more operational level remains a slow process. Both sides are wary of further antagonizing the PRC. Nevertheless, Hanoi was gratified when in early October 2014 the US partially lifted its prohibition on the sale of lethal

3I. Carlyle A. Thayer, Vietnam-United States Strategic Partnership, Thayer Consultancy Background Brief, March I3, 20I3.

32. Author's interview with an official of the Institute for South China Sea Studies, Diplomatic Academy of Vietnam, in Misawa, Japan, May 20, 2013.

33. Carlyle Thayer, Vietnam: Assessing President Truong Tan Sang's Visit to the United States, Thayer Consultancy, July 28, 2013. 
weapons to Vietnam. The new, more liberal policy would apply only to naval systems, according to the State Department, and came about because Vietnam had ostensibly improved its human rights record. This rationale was immediately rejected, however, by Human Rights Watch, whose Asia director, John Sifton, declared, "Vietnam's record on political prisoners is bad and getting worse.” Regardless, Washington hopes to strengthen Vietnam's coast guard, and last September the country's Navy commander-in-chief, Admiral Nguyen Van Hien, visited the United States and talked with Navy Secretary Ray Mabus about joint naval exercises. A few days before the partial lifting of the embargo was announced, Assistant Secretary of State for East Asian and Pacific Affairs Daniel Russel stated that Vietnam's strategic location was a good reason to work more closely with the country. The specific weapons to be provided will be decided on a "case by case" basis and could include both boats and aircraft. (Washington approved the sale of non-lethal military equipment to Vietnam in 2006.)

Spokespersons in the State Department assured other states in the region (read: China) that the sale would not destabilize the arms balance and that the weapons systems purveyed would be strictly defensive and heavily focused on Vietnam's coast guard. However, given Hanoi's allegations that Chinese ships and aircraft regularly violate Vietnam's South China Sea claims, any buildup of Hanoi's maritime defensive capacity might be seen differently by Beijing. Among the first systems to be sold to Vietnam will probably be P-3 maritime surveillance planes. The US Navy is replacing this model with the more capable P-8; nevertheless, the older P-3s are able to loiter in anti-submarine warfare mode for up to half a day. However, the US sales may be mostly "symbolic," since Vietnam's arms are predominantly Russian in origin — the exception being anti-submarine warfare capabilities.

Two US partners are also involved in providing arms to Vietnam. Last August, Japan's foreign minister said that his country would transfer six second-hand vessels and other equipment to improve Hanoi's maritime law enforcement. In September, the Japanese Diet discussed the provision of new patrol craft. In a December 2013 meeting, Prime Ministers Nguyen and Abe talked of their "convergence of interests in the East and South China Seas." And India offered a \$roo million credit to Vietnam, for the purpose of buying new naval vessels, during Prime Minister Nguyen's October visit to New Delhi. While there is no coordination among Washington, Tokyo, and New 
Delhi, it is clear that all three are assisting Vietnam's efforts to improve maritime domain defense. ${ }^{34}$

\section{A SUMMATION}

Southeast Asian states generally endorse all facets of the US rebalance, particularly enhanced military deployments, additional joint exercises, capacity-building for the region's armed forces, and robust participation in ASEAN-based international organizations. For realists, these activities contribute to regional stability during an era that many view as one of China's bid for regional hegemony. A substantial US presence cools the prospect for competitive regional Great Power competition and even possible regional Great Power war. ${ }^{35}$

At the June 2013 Shangri-La Dialogue, the Pacific Command head, Admiral Locklear, emphasized that the rebalance is not directed against any country but is designed to help create a security environment in which all regional powers, including China and India, can also make positive contributions. Strategically, Locklear averred: "We don't take sides, but we have an interest.... On the issue of sovereignty... maintaining the status quo is very important." By this he meant that any changes in oceanic territorial dispositions must be achieved only through negotiations. As for concerns about the long-term impacts of US defense budget constraints, the admiral tried to reassure dialogue participants: "Even under the most severe budgetary predictions, the US defense will still make up 40 percent of all defense spending in the world." ${ }^{36}$ In discussing the rebalance with Asian partners, US officials have emphasized that the strategy engages China rather than containing it. Going back to Robert Zoellick in the George W. Bush administration, the hope has been to induce China to be a responsible partner of the United States in the Pacific. ${ }^{37}$ Meanwhile, US forces remain on station, and the Departments of Defense and State continue to help allies and partners develop their own defense capacities.

34. The preceding discussion is drawn from Simon, "US-Southeast Asian Relations: Diplomatic Gambits," 5I-52.

35. Brooks, Ikenberry, and Wohlforth, "Don't Come Home, America," 37.

36. Wendell Minnick, "America's Juggling Act with China," Defense News, June Io, 2013, 4.

37. Ralph Cossa and Brad Glosserman, "Regional Overview: Continuity Prevails for Better and Worse," Comparative Connections I5, no. I (May 2013): 4-5. 
Unsurprisingly, China does not accept the US interpretation of the rebalance. The PRC's new foreign policy leadership, consisting of Wang $\mathrm{Yi}$ as foreign minister and Yang Jiechi, his predecessor and now state counselor, are known for their hard line toward the United States. As foreign minister, Yang insisted that Washington reduce its participation in AsiaPacific discussions. He also noted that PRC trade with Asia outstripped its total trade with the United States and Europe combined, reaching \$I.2 trillion in 2012. ${ }^{38}$ In their October 2013 presentations at APEC and the ASEAN-China Summit, both Xi Jinping and Prime Minister Li Keqiang emphasized China's economic importance to Southeast Asia, in contrast to America's lower trade profile.

China's leaders also see an American decline in its disengagement from Iraq and Afghanistan without victory-indications that US military superiority does not translate into achievable policy objectives. Moreover, these US policy objectives are fundamentally hostile to PRC concerns. The promotion of democracy and of human rights are seen as efforts to undermine the legitimacy of the Communist Party government. Additionally, Washington's support for the PRC's Asian neighbors in all of Beijing's maritime territorial disputes is viewed as a new containment policy that seeks to curtail China's regional influence. ${ }^{39}$ Beijing also objects to the Pacific Command's close-in surveillance of Chinese ports and airfields inside China's EEZ. (China treats its EEZ as an extension of its territorial waters.) Thus, Beijing sees US EEZ surveillance as a hostile act. ${ }^{40}$

China's maritime capabilities may now be sufficient to challenge American dominance in East Asian waters. In 20I3, the PLAN deployed ships from all three of its regional fleets to carry out a joint exercise in the South China Sea. In July 20I3, China created a new, unified Coast Guard Agency, with 16,00o personnel operating extensively in the South China Sea. PRC fishing fleets regularly work in the disputed Spratly islands. Chinese media refer to the country's maritime resources in its Io,ooo "territorial

38. Jane Perlez, "China Names New Team to Secure Its Place in Asia and Face U.S. Competition," New York Times, March 17, 2013, 15.

39. For a good overview of the impact of China's military modernization on its Asian neighbors, see Andrew Shearer, "Southeast Asia and Australia: Case Studies in Responding to China's Military Power," in Strategic Asia 20I2-20I3: China's Military Challenge, ed. Ashley Tellis and Tavis Tanner (Seattle, WA: National Bureau of Asian Research, 20I2), 24I-76.

40. "U.S. Vessels Approaching China May Be Investigating Ports and Submarine Bases," People's Daily Online, September 6, 2013. 
islands." ${ }^{41}$ The PLA is also expanding military exercises with Southeast Asian states. Particularly notable was PRC Defense Minister Chang Wanquan's visit to Thailand in May 20I3, where he spoke of creating a ChinaThai equivalent to Cobra Gold. ${ }^{42}$

In sum, PLAN ships now deploy in water around islands that the Philippines and Vietnam also claim. China has stationed a frigate at Scarborough Shoal whose role is to shoo away Philippine fishing boats. As a result of these deployments, the United States and its Southeast Asian partners are presented with a fait accompli: Beijing claims that it has no intention of interfering with freedom of navigation but will continue to enforce its territorial claims, about which the US position has been not to take sides. None of the Southeast Asian claimants in the South China Sea possess the capabilities to balance China's growing maritime capabilities and assertiveness. The United States insists that despite a reduced defense budget its Pacific presence will remain robust. However, ongoing Congressional budget crises-if they continue-may cause sufficient consternation among Washington's allies and partners that future reliance on US pledges of support may be impaired. America's rebalance is designed to provide Washington's Southeast Asian partners with the ability to hedge against China's hegemonic ambitions. If the credibility of the rebalance is undermined by reduced funding and internecine US political warfare, there could well be a shift in the region's security orientation toward the PRC, and the "rebalance" could become an "unbalance."

\section{CODA: THE PRESIDENT IN SOUTHEAST ASIA-AT LAST}

In addition to the allocation of material resources, the importance the Obama administration attributes to the rebalance may be determined by the level of attention given by high-level US leaders to Southeast Asia. When the president postponed his long-planned October 2013 trip to the region, he sent in his stead Secretary of State John Kerry, followed by Secretary of Defense Chuck Hagel and Pacific Commander Admiral Locklear. However, none of

4I. Robert Sutter and Chin-hao Huong, "China-Southeast Asian Relations: China's Toughness on the South China Sea-Year II," Comparative Connections, September 2013, 62-63.

42. Phuong Nguyen and Brittany Billingsley, "China’s Growing Military-to-Military Engagement and Thailand and Myanmar," Cogit Asia (Center for Strategic and International Studies), September I2, 2013. 
these high-level officials could fully replace the psychological assurance that a visit by the US president provides. ${ }^{43}$

The president's April 2014 appointments in Malaysia and the Philippines illustrate two separate components of the rebalance. While Kuala Lumpur has no formal defense relationship with the United States, Malaysia's armed forces have exercised with the American navy and air force for decades and have also purchased US military equipment. Nevertheless, the primary rebalance takeaway from President Obama's 20I4 visit is in economic relations, particularly the prospect of Malaysia's adherence to the Trans-Pacific Partnership (TPP). Much like other Asian governments (Japan, Republic of Korea) declaring an interest in the trade expansion potential of the TPP, Malaysian Prime Minister Najib Razak must cope with protectionist interests.

Obstacles to Malaysia's successful completion of TPP negotiations include State-Owned Enterprises, the preferential employment opportunities given to ethnic Malays (bumiputera), government procurement preferences for local companies, lax environmental protection, foreign investor/state dispute settlement mechanisms, intellectual property rights protection, and the potential of the trade pact to drive up the costs of pharmaceuticals by prohibiting the purchase of generic drugs. ${ }^{44}$ Negotiations continue. Nevertheless, the two countries managed to upgrade their bilateral relations to a Comprehensive Partnership, and Malaysia officially endorsed the antiWMD Proliferation Security Initiative, with which it had been informally cooperating for some time. The joint statement of the two leaders indicated for the first time Malaysia's support for the principle of international arbitration on the South China Sea-a procedure the Philippines is currently pursuing with the UN arbitral tribunal on the law of the sea.

Central to rebalance achievement was the president's Philippine discussions. Unlike Malaysia, the focus in Manila was security. As President Obama arrived in the Philippines, two years and eight rounds of negotiations were rewarded with the conclusion of a Io-year Enhanced Defense Cooperation

43. For an assessment of Southeast Asian reactions to President Obama's postponement of his October 2013 visit to the region, see Sheldon Simon and Carl Baker, "U.S.-Southeast Asian Relations: Obama Passes," Comparative Connections, January 2014. 47-56.

44. These are enumerated in "Progress in Trade Pact Issues," New Straits Times (Kuala Lumpur), April 29, 20I4; "Najib Tells President Obama Malaysia's 'Sensitivities' Prevent Signing of TPP," Straits Times Online (Singapore), April 28, 20I4. 
Agreement (EDCA). It emphasizes “capacity building” for the country's armed forces in "external defense, maritime security, and humanitarian assistance and disaster relief." So far, the EDCA is just a framework, the specifics of which have yet to be determined. It will include the construction of new facilities for US personnel and equipment within Philippine bases, to which Philippine forces will have access; so there is no return to US bases on Philippine territory. American forces will rotate through these facilities, as in the current arrangements in Mindanao and in Darwin, Australia. Discussions in Manila focused on US assistance for Philippine armed forces' transition from internal to external defense, particularly in maritime security. ${ }^{45}$

Soon after the EDCA was negotiated, in April 2014, objections from nationalists and anti-Americans in the Philippine Congress were voiced. Petitions were filed in the Philippine Supreme Court to nullify the agreement, which was vigorously defended by the Aquino government. In an October filing by the solicitor general of the Philippines, the EDCA was seen as necessary "to achieve a minimum credible defense to the manifold security concerns in the West Philippine Sea. [It] enhances the existing contractual security apparatus between the Philippines and the US up through the Mutual Defense Treaty and the Visiting Forces Agreement." Disputing the opposition claim that the EDCA required Philippine Senate ratification because it was a treaty, the solicitor general insisted that the agreement was "only an implementation of existing treaties." In midNovember, during oral arguments on the petition to reject the EDCA, several Supreme Court justices stated that the petitioners should argue their concerns before the Senate rather than the Supreme Court, as the court was not the proper venue.

Additional arguments against the EDCA are that it permits the United States to establish bases in violation of the Philippine constitution. Defenders point out that any new construction authorized by the EDCA would take place on Philippine bases and therefore would belong to the Philippines. Perhaps the core complaint about the EDCA is that it does not guarantee US involvement in the event of a direct military confrontation over disputed waters and landforms in the South China Sea. After all, the United States has

45. Mong Palatino, "Obama in the Philippines: Our Goal is Not to Contain China," The Diplomat, April 29, 20I4; "Joint Press Conference by Presidents Obama and Aquino," Malaconang Palace, Manila, White House Office of the Press Secretary, April 29, 2014. 
often said that it does not take sides in South China Sea territorial disputes. Nevertheless, in his April 20I4 visit to Manila, President Obama assured the Philippines that the US commitment to the Mutual Defense Treaty was "ironclad." Moreover, enhanced US-Philippine military exercises and more frequent US Navy port calls would presumably provide Manila with diplomatic leverage in its disputes with China and reinforce deterrence. Opponents doubt the deterrent value of the EDCA and point to the difference between the US commitment to defend Japan's administration of the Senkaku Islands and less definitive interpretation of what Washington would do in the event of, say, a Chinese attack on Scarborough Shoal or on Philippine personnel patrolling the region. ${ }^{46}$

\section{CONCLUSION: SOUTH CHINA SEA REDUX}

Over the past several years, the Obama administration has repeatedly insisted that it does not take sides on South China Sea sovereignty disputes. The US has argued that disputes should be resolved peacefully through negotiations based on international law. Now, however, Washington appears to have taken a more proactive position. In mid-December 20I4, the State Department published a detailed rebuttal to the Chinese nine-dashed-line claim to over 80 percent of the South China Sea. The State Department document argues essentially that China's claim ignores UNCLOS and contravenes its provisions. Both the Philippines and Vietnam praised the US analysis. Moreover, the day before the US report was released, Hanoi submitted its own position paper to the UN arbitral tribunal that appears to endorse Manila's request for arbitral tribunal rulings. It seems that the United States and Vietnam have aligned with Manila's submission. China's consistent rejection of UN jurisdiction in these matters is in stark contrast and appears to place the PRC outside the limits of international maritime law.

46. Greater elaboration may be found in Simon, "US-Southeast Asian Relations: Diplomatic Gambits," 48-49. 